\title{
FOLKEMUSEENE I UTLANDET OG DET FREMTIDIGE "MUSÉE FRANÇAIS DES ARTS ET TRADITIONS POPULAIRES”
}

\author{
Georges-Henri Rivière
}

Folgende artikkel ble skrevet av GHR i 1936. Han hadde da $i 7$ àr vert underdirektor ved Musée d'Ethnographie du Trocadéro i Paris, og arbeidet med omorganiseringen av dette museet, som 1937 skulle gjenoppstå som Musée de l'Homme. Han planla samtidig, bl.a. under inspirasjon av de nordiske folkemuseene, losrivelsen av museets franske avdeling og opprettelsen av et eget fransk folkemuseum, det fremtidige Musée National des Arts et Traditions populaires.

Teksten inneholder hovedelementene av den museologiske filosofi som kjennetegner GHRs arbeid. Den beskriver et program for utviklingen av folkemuseene i Frankrike, som GHR gjennom mange vanskeligheter og med mer eller mindre hell, forsøkte å gjennomfore under resten av sitt liv:

La oss se nærmere på hva som har vært gjort $\mathrm{i}$ utlandet når det gjelder folkemuseene. Vi må først konstatere at disse museene utgjør en meget sammensatt gruppe. Vi kan dele dem inn i tre hovedtyper.

Museer for generell etnografi, som i Hamburg eller Warszawa, utgjør den første gruppen. De har en europeisk avdeling, ved siden av avdelinger for Asia, Afrika, Amerika og Oseania.

I den andre gruppen finner vi museer som ikke bare omfatter folkekultur, men også kulturen fra sosiale eliter, arkeologi, til og med kunst- og naturvitenskapene; og dette innenfor ei hovedramme som enten er internasjonal, nasjonal eller regional. Det mest berømte og mest populære er Nordiska Museet i Stockholm, skapt av Artur Hazelius i 1873. [...] Dette museet begrenser seg ikke til den svenske kulturhistorien fra de siste 400 år, selvom det utgjør dets hovedarbeidsfelt. Samlingene innholder også gjenstander fra middelalderen og forhistorien, og til og med fra 
118 den moderne tid. I tillegg vier dette museet en stor plass til kulturen fra de andre nordiske folk. [...] Videre kommer nasjonale museer, som Norsk Folkemuseum i Oslo. [...] Dette museet innholder avdelinger for adelen og borgerskapet, religionen, folkekunst fra bondesamfunnet, produkter fra håndverk og småindustri, og samferdsel. Til samme type hører Rigas historiske museum, Estonias nationalmuseum i Tartu, Litauens nasjonalmuseum i Kaunas og Finlands nasjonalmuseum. [...] Blant de regionale museene vil jeg nevne National Museum of Wales i Cardiff, og de utallelige Heimatmuseen i Tyskland. [...] Et av de mest bemerkelsesverdige er Rhinenmuseet i Köln [Römisch-Germanisches Museum], som representerer en storslagen syntese av alle sider ved regionens kultur og historie. [...]

I den tredje gruppen finner vi museer som utelukkende er viet folkekulturen. Museum für Volkskunde i Wien omfatter - så langt det lar seg gjøre - alle europeiske folk. Prahas etnografiske museum er et museum om den nasjonale folkekulturen, og det gjelder også Dansk Folkemuseum i København, Hungarns nasjonalmuseums etnografiske avdeling, og Museum für Deutsche Volkskunde i Berlin. Blant de regionale museene vil jeg nevne Transylvanias etnografiske museum i Cluj, Kroatias etnografiske museum i Zagreb, Tyroler Volkskunstmuseum i Innsbruck, Musée de la Vie Wallonne i Lièges. Det siste er karakterisert ved et spesielt interessant program, idet museet ikke begrenser sin virksomhet til kun å gjelde fortiden, men ser det som sin hovedmålsetting å verne fra ødeleggelse og glemsel alle slags gjenstander, dokumenter og opplysninger som dokumenterer det Wallonske folks levesett før og nå. [...] Jeg vil dessuten tilføye at de fleste av disse museene har store magasiner som er tilgjengelige for forskerne, og hvor det meste av samlingene er klassifisert. De har også biblioteker, bildeog lydarkiv, og avdelinger for utdanning og folkeopplysning.

Nå vil jeg ta meg av spørsmålet om friluftsmuseene, en museumstype som siden Hazelius opprettet det første i Skansen, har hatt en utrolig utvikling i Danmark, Sverige og Norge. Disse museenes målsetting er, i følge en publikasjon fra Norsk Folkemuseum på Bygdøy, å få de besøkende til å lære å kjenne - med sine egne øyne - livet og sivilisasjonen fra eldre tider. "Gjenstandene er ikke isolert som i en vitenskapelig samling, men utstilt i grupper for å lage tablåer. Vi ser hele rommet med sin innredning. Våre forfedres liv er bokstavelig gjenoppstått og brakt nærmere oss slik at vi kan ta på og føle det”.

Skansen befinner seg $\mathrm{i}$ et kupert og skogskledd område med praktfullt utsikt over Stockholm. Museet innholder mer enn hundre originale bygninger, ikke bare fra bondesamfunnet, men også av adelig og borgelig opprinnelse, som har blitt flyttet og omhyggelig gjenreist. [...] Her ser vi vindmøller, verksteder, og til og med en kirke, - en ekte kirke hvor en kan gifte seg. Kvinner i regionale bunader passer på husene som er møblert, og broderer og vever i publikums nærvær. En samisk familie levendegjør en nomadeleir. I restauranten, som ligger i nærheten av en zoologisk hage, kan en smake på gastronomiske spesialiteter fra alle regioner. En stor uteplass fungerer som ramme for folkefester. Denne mikrokosmen av Sverige fikk 1.300000 besøkere ifjor, noe som 
sier mye om den viktige rollen Skansen spiller i det nasjonale liv.

Friluftsmuseet i Oslo er mer intimt, men ikke mindre gripende. Museets underholdningsverdi har vært bevisst neglisjert: det finnes få eller ingen forestillinger, fester, restauranter. Men derimot har museet et fint naturmiljø hvor gårdene - som verdt à merke har som regel sine uthus - er skjult fra hverandre bak vegetasjonen og terrengets ujevenheter. Her finner vi ikke bare bondegårder, men også noen enkle bygårder langs en liten gate.

Friluftsmuseet i København er beslektet med det forrige, bortsett fra at museet befinner seg i et flatt land slik at terrenget ikke tillatter så sinnrike arrangementer.

Til slutt, friluftsmuseet i Arnhem i Nederland viser bygninger spredt på et stort område, dominert av en praktfull samling av vindmøller.

Denne oversikten er langt fra fullstendig, men jeg har valgt å fortelle om museene jeg har personlig besøkt. Jeg kommer senere til å holde en presentasjon over folkemuseene i Sovjetunionen, som jeg kommer til å besøke i sommer. [... slutt for artikkelens 1. del]

Den franske folkloren har allerede vært gjenstand for et meget omfattende arbeid. Men til tross for museer i stadig vekst og en blomstrende vitenskapelig virksomhet, er det nå sterkt påkrevet å orientere seg mot to nye arbeidsfelt.

For det første, bør det i Paris opprettes et sentralt museum som skal være den unge og livskraftige arvtaker av den tidligere franske avdeling ved Musée d'Ethnographie du Trocadéro. [...] Både Sverige, Norge, Tyskland, Tsjekkoslovakia, Romania, de Baltiske statene og mange andre land, viser oss eksempler på nasjonale museer som langt fra å utvikle seg til fortrengsel for de regionale museene, tvertimot deltar broderlig i deres virksomhet. Jeg har for denne institusjonen i Paris tenkt ut en plan og en virksomhet som ikke ville kopiere, men utfylle de regionale museene. La de forskjellige museene utvikle seg i forhold til deres egne topografiske og metodiske rammer, til deres egne ressurser og ånd. La oss i Paris skape et museum som ikke er summen av de regionale museene, men et syntesemuseum. La oss bli inspirert til å foreta denne syntesen og utvikle den videre av Musée de la Vie Wallonne og Rhinenmuseet. La denne syntesen uttrykke mer det sosiale miljøet enn produksjonen. La oss legge større vekt på enkle store linjer hentet fra selve livet, som det store publikum er fortrolig med, enn på gjenstandstypologi og teknisk utvikling.

Jeg vil nå legge fram noen korte refleksjoner vedrørende folkemuseenes struktur. [...] En kan, uten å feste seg til deres historiske opprinnelse, skille mellom fire hovedutviklingsstadier.

Opphopningsstadiet: museet overtar hva som helst, fra hvor som helst og hvem som helst, som blir utstilt hvordan som helst. Et uforsvarlig museum.

Samlingstadiet: museet organiserer sine samlinger utfra en metodisk plan, viser alt det har, eller prøver ihvertfall å gjøre det. Dette er magasin-museet, som er skapt for konservatorene og bare for dem.

Seleksjonsstadiet: utvalget av de vakreste gjenstandene, når det dreier seg om et kunstmuseum, eller seleksjon av representative typer, når det dreier seg om et vitenskapelig museum. Dette museet henven- 
120 der seg til en elite av spesialister og forskere.

Syntesestadiet: det eneste museet som har gyldighet for det brede publikum. Godt utvalgte gjenstander er ledsaget av bildedokumentasjon og tekster i stort format. Et museum som kan besøkes uten guide. Dette stadiet er f.eks. nådd i mange museer i Sovjetunionen.

Det ideelle museet vil forene de tre siste stadiene. Samlingsstadiet i magasinene. Seleksjonsstadiet $i$ en serie av saler tilgjengelige for publikum, plassert ved siden av gallerier hvor syntesen blir presentert. I begynnelsen av hvert av disse galleriene vil publikum finne en introduksjon til dets innhold - og på slutten - hypoteser og sammenligninger som refererer til det de har sett.

Når det gjelder vårt museum i Paris, ser jeg på denne institusjon bare som et syntese-museum, på grunn av eksistensen av det store antallet regionale folkemuseer. Det skal kompletteres med en omfattende dokumentasjonsavdeling, med den hensikt a orientere forskernes interesse mot regionene.

Hva kunne vi kalle dette museet? Jeg ser bort fra betegnelsen "de folklore" (folkloristisk), som er et rent vitenskapelig uttrykk. Jeg foreslår "Musée Français des Arts et Traditions Populaires" (Det franske museum for folkekunst- og tradisjoner). ${ }^{1}$

La oss nå gå over til spørsmålet om friluftsmuseene. Jeg ble i fjor bedt om å utrede muligheten for opprettelsen av et friluftsmuseum for hele Frankrike. Etter å ha lenge reflekter over spørsmålet, konsultert de høyeste vitenskapelige myndighetene, og besøkt flere friluftsmuseer i utlandet, er jeg kommet til den konklusjon at en burde velge en annen løsning for Frankrike. Jeg er av den oppfatning at en burde opprette mange små friluftsmuseer, i stedenfor ett stort museum, og plassere dem i tilknytning til offentlige eiendommer, som historiske bygninger, statsskoger, naturreservater. Disse museene kunne, i enkelte tilfeller, kombineres med ungdomsherberger, og på denne måten tilføre disse en verdifull kulturell dimensjon. Kunne ikke Frankrike, som har et så stort kulturmangfold, opprette slike museer i sine regioner, når Sverige allerede har 150? Vi ser klart den betydningsfulle rollen slike institusjoner kunne spille i landets sosiale og kulturelle liv. *

\section{GHR NOTE:}

* de historiske begivenhetene som har foregått siden mitt innlegg ble holdt, gir disse tankene en økt aktualitet. Pga omfattende økonomiske endringer er det mer nødvendig enn aldri før å dokumentere det franske bondesamfunnets tradisjonelle levesett. I tillegg vier vår nåværende regjering ${ }^{2}$ meget stor oppmerksomhet til spørsmål knyttet til utdanning og folkeopplysning.

\section{OVERSETTERS NOTER.}

1. Det nye museet som ble opprettet i 1937 fikk navnet "Musée national des arts et traditions populaires". GHR ønsket egentlig - noe han senere ofte ga uttrykk for - å kalle det bare "Musée français" (fransk folkemuseum). Det var betegnelsen "arts populaires" (folkekunst) han tok avstand fra. Men det endelige navnet ble fastlagt på høyere hold.

2. Folkefrontens (Front Populaire) regjering dannet etter valget i juni 1936. 